Zuzanna Raszczyk*

ORCID: 0000-0001-6762-3307

University of Wrocław

https://doi.org/10.19195/1733-5779.34.1

\title{
Mandatory Disclosure Rules (MDR) and the professional secrecy of a tax advisor
}

\section{JEL Classification: K34}

Keywords: Mandatory Disclosure Rules, professional secrecy, tax advisor, tax evasion, MDR, closer monitoring, tax system, ordinance

Slowa kluczowe: raportowanie schematów podatkowych, tajemnica zawodowa, doradca podatkowy, unikanie opodatkowania, MDR, uszczelnianie, system podatkowy, ordynacja

Abstract: Mandatory Disclosure Rules (MDR) have been introduced to the Polish legal system and have been in force since 1 January $2019 .{ }^{1}$ It is a regulation imposing an obligation of disclosing tax planning schemes to fiscal administration bodies, and its purpose is to protect the tax system against tax evasion and dishonest lowering of public levies. This regulation introduced significant changes in the scope of practising the profession of a tax advisor with a particular consideration of a change made in the professional secrets of a tax advisor. These changes gave rise to many controversies and doubts both in the doctrine as well as among the tax advisors' self-governing council. The newly-introduced institution may have a negative impact on the practical aspects of performing the profession of tax advisor. The aim of the work is to discuss and analyse the Mandatory Disclosure Rules in terms of professional confidentiality of a tax advisor, as well as to indicate the practical effects of the introduced amendment. The scientific article uses the formal-dogmatic method, analysing the legal text and its interpretation, including jurisprudence.

* Scientific Tutor (Opiekun naukowy) — prof. Katarzyna Kopyściańska

1 The basis for the introduced change was the implementation of Council Directive (EU) 2018/822 of 25 May 2018 (hereinafter: Directive). Amending Directive 2011/16/EU as regards mandatory automatic exchange of information in the field of taxation in relation to reportable cross-border arrangements, the so called MDR directive.

Studenckie Prace Prawnicze, Administratywistyczne i Ekonomiczne 34

Studenckie Prace Prawnicze, Administratywistyczne i Ekonomiczne 34, 2020

(C) for this edition by CNS 


\section{Raportowanie schematów podatkowych (MDR) a tajemnica zawodowa doradcy podatkowego}

Raportowanie schematów podatkowych (MDR - Mandatory Disclosure Rules) zostało wprowadzone do polskiego porządku prawnego i obowiązuje od 1 stycznia 2019 roku $^{2}$. To regulacja nakładająca obowiązek raportowania schematów podatkowych do administracji skarbowej, mająca na celu ochronę systemu podatkowego przed unikaniem opodatkowania oraz nieuczciwym zaniżaniem danin publicznych. Regulacja wprowadziła istotne zmiany w zakresie wykonywania zawodu doradcy podatkowego, ze szczególnym uwzględnieniem zmiany dokonanej w tajemnicy zawodowej doradcy podatkowego. Zmiany te wzbudziły wiele kontrowersji i wątpliwości zarówno w doktrynie, jak i wśród samorządu doradców podatkowych. Nowo wprowadzona instytucja może mieć negatywny wpływ na praktyczne aspekty wykonywania zawodu doradcy podatkowego. Celem pracy jest omówienie i analiza raportowania schematów podatkowych pod kątem tajemnicy zawodowej doradcy podatkowego oraz wskazanie praktycznych skutków wprowadzonej zmiany. $\mathrm{W}$ artykule naukowym zastosowano metodę formalno-dogmatyczną, poddając analizie tekst prawny oraz jego interpretację, w tym orzecznictwo.

\section{Origin of Mandatory Disclosure Rules}

Mandatory Disclosure Rules have their origin in the solutions proposed by the Organisation for Economic Cooperation and Development (hereinafter: OECD) and more specifically within the BEPS initiative. ${ }^{3}$ The BEPS package is a comprehensive set of instruments (15 actions), the purpose of which is to counteract the practices aimed at counteracting the lowering of the taxable base and also the transfer of profits. The package outlines certain assumptions, simple minimum standards, consistent solutions, as well as guidelines referring to taxation which can be implemented by states into their legal systems. ${ }^{4}$ It was included in Action no. 12 within the BEPS action plan, under the name of "Introduction of a requirement to disclose the used aggressive tax strategies by taxpayers". 5 The BEPS action plan refers to the issue of tax evasion and the ways of counteracting dishonest lowering of public levies, with a particular consideration of tax planning

2 Podstawą wprowadzonej zmiany była implementacja Dyrektywy Rady Unii Europejskiej (UE) 2018/822 z 25 maja 2018 roku, zmieniającej dyrektywę 2011/16/UE w zakresie obowiązkowej, automatycznej wymiany informacji w dziedzinie opodatkowania $\mathrm{w}$ odniesieniu do podlegających zgłoszeniu uzgodnień transgranicznych, tak zwanej dyrektywy MDR.

3 The term BEPS (Base Erosion and Profit Shifting) refers to the strategy of tax planning that uses gaps and discrepancies in tax law for hiding profits or transferring them to places in which a taxpayer discloses small activity or its complete lack thereof, but where taxes are low, which results in low taxation or no taxation with income tax.

4 A. Wieśniak-Wiśniewska, M. Czerwiński, “Świat podatków po projekcie BEPS i jego wpływ na polskich podatników”, Przegląd Podatkowy 6, 2016, pp. 22-25.

${ }^{5}$ Ibidem, p. 25. 
that uses gaps and discrepancies in tax law. The package was published on 19 July $2013{ }^{6}$

Based on the solutions proposed by the OECD within the mentioned BEPS action plan, a Directive was created as regards mandatory automatic exchange of information in the field of taxation in relation to reportable cross-border arrangements. That Directive imposed an obligation to communicate information on reportable cross-border arrangements. ${ }^{7}$

Introducing the Directive resulted in passing an act. ${ }^{8}$ The implementation of the Directive to the Polish legal system was expressed in chapter 11a section III added to the act. ${ }^{9}$ The provisions of the mentioned chapter have been in force since 1 July $2019 .{ }^{10}$

\section{Description of Mandatory Disclosure Rules}

The primary purpose of introducing Mandatory Disclosure Rules indicated by the OECD and the EU legislator was the protection of tax systems against tax evasion and dishonest lowering of public levies. As pointed out by the Ministry of Finance: ${ }^{11}$

MDR are particularly targeted at enabling tax administration to have access to information about potentially aggressive planning or abuses connected with tax planning, as well as information about the promoters and those that use tax planning schemes. These regulations should also discourage taxpayers and their advisors from implementing the arrangements which could constitute tax evasion at taxpayers'.

The subject of MDR is disclosing information to fiscal administration about the use of a tax scheme. The creation of information obligation depends on fulfilling the definition of a tax scheme by making arrangements or transactions, and in the case of schemes other than tax cross-border schemes also the criterion of a qualified user. In the scope of reporting tax schemes three kinds of schemes which are

${ }^{6}$ M. Jamroży, P. Domaszyńska, "XI Debata Podatkowa: Raportowanie schematów podatkowych”, Przeglad Podatkowy 7, 2019, p. 6.

7 M. Wilk, "Ujawnianie schematów podatkowych a tajemnica zawodowa doradcy podatkowego", Przeglad Podatkowy 2, 2019, p. 16.

8 The Act of 23 October 2018 on amending the Personal Income Tax Act, the Corporate Income Tax Act, the Tax Ordinance Act and certain other acts (Journal of Laws [Dz.U.] of 2018 item 2193), hereinafter referred to as the Amending Act.

9 The Act of 29 August 1997 - Tax Ordinance Act (consolidated text of the Journal of Laws [Dz.U.] of 2019 item 900), hereinafter referred to as T.O.

10 A. Ladziński, D. Wasiul, “O nieprawidłowej implementacji dyrektywy 2018/822 (MDR) i jej konsekwencjach", Przegląd Podatkowy 5, 2019, p. 9.

11 https://www.podatki.gov.pl/mdr/raportowanie-schematow-podatkowych-mdr/ (accessed: 17.04.2020). 
subject to the obligation to disclose information can be distinguished: tax scheme, standardised tax scheme, and cross-border tax scheme. ${ }^{12}$

The obligation to disclose information about tax schemes may pertain to three categories of entities: promoter, user and supporter. In accordance with Article 86a $\S 1$ point 8 of T.O., a promoter is an individual, a legal entity or an organisational entity without corporate, without legal personality, in particular a tax advisor, attorney, attorney-at-law, employee of a bank, or some other financial institution advising clients, also in the cases when they have no place of residence, registered office or management in the territory of a country. An entity fulfils the role of a promoter if in the scope of the conducted activities: they prepare an arrangement, offers an arrangement, makes available the prepared arrangement, implements the prepared arrangement, or manages the implementation of an arrangement. While in accordance with Article 86a $\S 1$ point 18 of T.O., a supporter is an individual, a legal entity or an organisational entity without corporate without legal personality, in particular an auditor, notary, a person rendering the bookkeeping services, accountant or financial manager, bank or some other financial institution, as well as its employee who when exercising due diligence generally required in the conducted activities, with the consideration of a professional nature of activity, area of specialisation and the subject of the conducted activities, undertook to provide, directly or via others, help, support or advisory regarding preparation, launching, organising, making available for implementation or supervising implementation of an arrangement.

\section{The impact of Mandatory Disclosure Rules on practising the profession of a tax advisor}

Having analysed the subject of reporting tax schemes and the persons obliged to perform it, it can easily be stated that its problematic aspects affect not only taxpayers conducting specific transactions but mainly their professional representatives or advisors. ${ }^{13}$ Tax advisors participating every day in many transactions and assisting to prepare them from the formal and tax side almost every day face a dilemma regarding the analysis of the obligation to report a given action conducted by a client to the National Tax Administration. From a philosophical point of view, such an obligation forces one to ask the question about the client's trust of their advisor and the will of clients to use the services of a professional assistant and advisor. So to speak, forcing by a statutory regulation to inform the National Tax Administration about the used tax schemes may arouse uncertainty in a client

\footnotetext{
12 A. Ladziński, D. Wasiul, op. cit., p. 9.

13 M. Jamroży, P. Domaszyńska, op. cit., pp. 7-8.
} 
as well as a reluctance to use the services, despite the client being unwilling to conduct a transaction in order to decrease tax or evade it. ${ }^{14}$

\section{The role, functions and legal regulations regarding the professional secrecy of a tax advisor}

Reporting tax schemes does not only affect practising the profession and advisory activities, but primarily the professional secrecy of a tax advisor. The profession of a tax advisor is one of those professions of public trust next to attorneys-at-law, notaries or attorneys. These professions are ones of high expertise, but also enjoy the trust of society due to the legal protection guaranteed to them by the acts pertaining to practising individual professions with the particular consideration of the provisions regulating the issue of professional secrets. One might venture an opinion that had there been no professional secrets in the above professions, their meaning and social role would be degraded. For the client's trust of an unknown advisor is based mainly on the obligation prescribed by the provisions of acts to keep secret the information obtained in the course of practising the profession which is significant on pain of criminal liability - Article 266 $\S 1 .{ }^{15}$ Referring directly to the Tax Advisory Act, ${ }^{16}$ and specifically to Article 37 it should be observed that:

1. A tax advisor has an obligation to keep secret the facts and information they learned while practising the profession.

1a. The obligation to keep professional secrets cannot be limited in time.

2. A tax advisor cannot be heard as a witness regarding the facts and information to which the obligation mentioned in section 1 applies, unless they have been released from that obligation in the manner specified in separate acts.

The above regulation shows that professional secrecy is an important and inseparable characteristic of that profession. Moreover, the obligation to maintain professional secrecy by tax advisors was emphasised by the National Convention of Tax Advisors in the Rules of Ethics of Tax Advisors ${ }^{17}$ and has been confirmed with an oath of a tax advisor: "I promise that as a tax advisor I will practise this profession being guided by the interest of my clients, with due diligence and accuracy, in accordance with the law, knowledge and the rules of professional ethics. I will keep secret the facts and information learned while practising the profession

14 Ibidem.

15 The Act of 6 June 1997 Criminal Code (Journal of Laws [Dz.U.] of 2019 item 1950), hereinafter referred to as CC.

16 Tax Advisory Act of 5 July 1996 (Journal of Laws [Dz.U.] of 2020 item 130).

17 Attachment to the resolution no. 237/2018 of the National Council of Tax Advisors of 22 May 2018 on adopting the consolidated text of the Rules of Ethics of tax advisors — https://kidp.pl/ strona.php/1541_zasady_etyki_doradcow_podatkowych.html (accessed: 17.04.2020). 
in relation to third parties", ${ }^{18}$ which proves the significance of the profession of a tax advisor.

The above quoted regulations originate in Article 17 of the Constitution of the Republic of Poland ${ }^{19}$ which is the principal legal act of our state. This regulation allows for the creation of a professional self-government of tax advisors as well as passing an act on tax advisory.

The primary cause of creating the profession of a tax advisor was the will to ensure the safety of clients as well as confidentiality regarding tax, financial and accounting information provided to advisors. In accordance with the position grounded in the doctrine, the professional secrecy of a tax advisor is expressed in an obligation to be silent, but also in the right to remain silent. ${ }^{20}$ They include not only the prohibition to disclose, in any form, information, documents or facts obtained while rendering advisory services, but also the information obtained as a result of disclosure by state bodies. ${ }^{21}$ The secret also pertains to any documents, letters or notes which contain contents about which an advisor learned in connection with conducting the activities of tax advisory and pertain to the subject of the rendered service. ${ }^{22}$ The professional secret of a tax advisor is defined broadly because it pertains to any information obtained by a tax advisor while rendering services. ${ }^{23}$ Moreover, in principle this obligation is absolute and unlimited in time, even releasing a tax advisor from secrecy by a client does not release them from it.

More confirmation of the significance and seriousness of the professional secrets of a tax advisor is the fact of existence of the provisions pertaining to interrogating tax advisors in the Code of Criminal Procedure. ${ }^{24}$ It appears from Article 180 of the CCP that tax advisors may be interrogated as to the facts comprising professional secrets only when it is necessary for the justice system, and moreover a given circumstance cannot be established on the basis of some other proof. Furthermore, the same conditions for interrogating a tax advisor in the scope of

18 https://kidp.pl/strona.php/1968_tajemnica_zawodowa_doradcy_podatkowego.html (accessed: 17.04.2020).

19 The Act of 2 April 1997 Constitution of the Republic of Poland (Journal of Laws [Dz.U.] of 1997 no. 78 item 483).

20 D. Szczygieł, "Commentary to Article 37”, [in:] Ustawa o doradztwie podatkowym. Komentarz, ed. A. Mariański, Warszawa 2015, p. 141.

$21 \mathrm{https}: / / \mathrm{kidp} . p \mathrm{pl} / \mathrm{strona} . \mathrm{php} / 1968$ tajemnica_zawodowa_doradcy_podatkowego.html (accessed: 17.04.2020).

22 E.A. Ambrożej, Doradztwo podatkowe jako instrument ochrony praw podatnika w Polsce, Białystok 2016.

${ }^{23}$ Decision of the Court of Appeal in Warsaw of 15 May 2008, case file no. II AKz 294/08, LEX no. 509771.

24 The Act of 6 June 1997 Code of Criminal Procedure (Journal of Laws [Dz.U.] of 2020 item 30), hereinafter referred to as CCP. 
information comprising professional secrets are given in Article $113 \S 1$ of the Penal and Fiscal Code. ${ }^{25}$

As observed by the Court of Appeal ${ }^{26}$ the scope of circumstances included in the release should be marked carefully. A general specification of the scope of release would result in that the release would not pertain to specific circumstances and would be carte blanche for the enforcement authorities that would freely release from professional secrecy. According to the court it is self-evident that it is the Claimant (Prosecutor) that is responsible for indicating and proving the conditions justifying the release from the obligation to keep the professional secrets of a tax advisor. In failing to fulfil such an obligation, a prosecutor risks the dismissal of a filed motion.

The Constitutional Tribunal ${ }^{27}$ pointed out that the legal regulations penalize violations of professional secrecy in various forms ranging from disciplinary to criminal liability.

The legislator does not treat the obligation to maintain professional secrecy solely as a private-law relationship occurring between advisor and client, but in Article 266 of the Criminal Code they provide for criminal liability of everyone "who, against the provisions of the act or an undertaken obligation, discloses or uses the information they learned about in connection with the performed function, public, social, economic or scientific activity".

In accordance with the above it should be observed that the professional secret of a tax advisor has been created as an obligation and not a privilege. ${ }^{28}$

In the light of the above regulation it is impossible to question the view that at the level of ordinary legislation, the secrecy of a tax advisor has been formed in the categories of an obligation. It is a statutory obligation and the sanction for violating it is not only civil-law liability in relation to a client, but also - at the motion of the injured party - a criminal sanction. For committing an offence sanctioned in Article $266 \S 1 \mathrm{CC}$ the penalty prescribed includes a fine, restriction of liberty or imprisonment for up to 2 years. ${ }^{29}$

25 The Act of 10 September 1999 Penal and Fiscal Code (Journal of Laws [Dz.U.] of 2020 item 19).

${ }^{26}$ Decision of the Court of Appeal in Wrocław of 18 September 2009, case file no. II AKz 472/09, LEX no. 1451899 (similarly: the Court of Appeal in Kraków in the decision of 19 March 2009, case file no. II AKz 64/09, LEX no. 1222109).

27 Judgement of the Constitutional Tribunal of 22 November 2004, case file no. SK 64/2003, LEX no. 133768.

$28 \mathrm{https} / / / \mathrm{kidp} . \mathrm{pl} /$ strona.php/1968_tajemnica_zawodowa_doradcy_podatkowego.html (accessed: 17.04.2020).

29 J. Piórkowska-Flieger, "Commentary to Article 266", [in:] Kodeks karny. Komentarz, ed. T. Bojarski, Warszawa 2017, LEX/el. 


\section{Mandatory Disclosure Rules and the professional secrecy of a tax advisor}

The amendment of the legal regulations was made with the Amending Act. The introduced change is a significant change, if not fundamental in the scope of practising the profession of a tax advisor and its protection. By virtue of the above mentioned act, Article 37 of the Tax Advisory Act was amended. The amendment consisted in adding point 2 in section 4 of the following wording: "The obligation mentioned in section 1 does not apply to the information: 2) communicated based on the provisions of chapter 11a section III of the Tax Ordinance Act of 29 August 1997".

The introduced amendment limited the professional secrecy of tax advisors to a large extent. It is a change significantly affecting the present work of tax advisors and the conditions or rendering it. The change gave rise to many controversies and doubts in the circle of tax advisors. ${ }^{30}$

The National Council of Tax Advisors (hereinafter the Council) took a position. ${ }^{31}$ In the position it presented many concerns and doubts in connection with the planned at that time (from 1 January 2019) amendment of the Tax Advisory Act.

In the adopted position the Council emphasised the fundamental meaning of the existence of professional secrecy of tax advisors as the guarantee of safety and trust between a client and their advisor. Also, exercising caution regarding the acceptance of the release from professional secrecy and paying attention to remembering to inform clients about the possibility of the occurrence of such a situation and the threats connected with that was recommended. ${ }^{32}$

Moreover, the Council also pointed to the fact of the failure to regulate many issues that appear during the practical interpretation and execution of the regulations. The doubts pertained i.a. to the degree and detail of information which a tax advisor is bound to obtain from a client. The information is to enable them to report correctly and completely. Moreover, the doubts also concern placing a limit on such a verification and if an advisor may base on the experiences of the contracting parties and report in accordance with them.

According to the position of the Council, ${ }^{33}$ one may observe a certain systemic inconsistency of the implemented solutions regarding reporting tax schemes. It is indicated that the aim of introducing the reporting is to obtain by the fiscal administration as comprehensive and full information as possible about the considered and used tax schemes. This information is to include such detailed transaction

30 M. Wilk, op. cit., pp. 20-21.

31 The position of the National Council of Tax Advisors of 18 December 2018 on professional secrecy in the context of the obligation to provide information about tax schemes.

32 Ibidem.

33 Ibidem. 
data as their amounts and the inclusion of information while filing declarations and returns. According to the Council it is the user that has full knowledge of the conducted transactions, and consequently has the complete data necessary for reporting, therefore it is the user that should be the entity responsible for providing a report. ${ }^{34}$

The National Council of Tax Advisors also adopted the second position on professional secrecy in the draft amendment to the Tax Ordinance Act ${ }^{35}$ - it concerns changes in the scope of reporting tax schemes. In the mentioned position, the Council indicated that introducing the MDR mechanism should not affect the professional secrecy of tax advisors by limiting it. It was pointed out that the mentioned changes "in an unauthorised way go into the essence of professional secrecy that binds persons practising the professions of public trust". Moreover, as in the position on professional secrecy in the context of the obligation to provide information on tax schemes, the lack of precision of the implemented regulations was pointed out, which is unacceptable with such a fundamental issue as limiting the professional secrecy of a tax advisor as it puts the taxpayer - the advisor's client - in a highly uncomfortable situation. ${ }^{36}$

To emphasise the significance of the case, a resolution ${ }^{37}$ was adopted based on which the National Council of Tax Advisors was bound to guard the professional secrecy of tax advisors through its protection and strengthening the obligation to observe it.

Bearing the above in mind, it needs to be observed that the introduced changes send shock waves across the circle of tax advisors. It means that it is a fundamental issue for them and something highly important. As indicated, the voice of a freelance profession in the scope of changes is a critical voice, indicating many difficult and often imprecise issues.

\section{Conclusions}

Summing up, it needs to be emphasised that the introduced amendment had a significant impact on performing the profession of a tax advisor as well as on advisors' relations with clients. Release from professional secrecy in the scope of information communicated when reporting tax schemes is a significant "depar-

34 Ibidem.

35 The position of the National Council of Tax Advisors of 11 September 2018 on professional secrecy in the draft amendment to the Tax Ordinance Act.

36 Ibidem.

37 Resolution no. 35/2018 V of the National Convention of Tax Advisors of 13 July 2018 on the operating plan of the National Chamber of Tax Advisors for years 2018-2021 — https://kidp.pl/ strona.php/2531_uchwala_nr_352018_v_krajowego_zjazdu_doradcow_podatkowych_z_dnia_13_ stycznia_2018_r_w_sprawie_progra.html (accessed: 17.04.2020). 
ture", a sort of novum from the earlier emphasised rule pertaining to the protection of professional secrecy of tax advisors due to its social significance.

It would need to be considered if evading or decreasing taxation is important and socially significant enough to cause the release from professional secrecy of a tax advisor. It should be clearly indicated that the maintenance of professional secrecy should be considered not only as an obligation of a tax advisor, but also as a fundamental right, as the obligation of secrecy is an absolute obligation. It leads to the creation of a doubt as to whether the "problem" of these regulations is to too serious in relation to the purpose which is to be achieved. In the opinion of the Author of this article, based on the legal regulations in force, opinions in the doctrine and the positions expressed by the National Council of Tax Advisors, it should be stated that a regulation was introduced with the violation of the basic rules pertaining to the protection of professional secrecy of a tax advisor. The adopted solutions impose a very heavy burden and responsibility on the advisors and cause anxiety among clients and sometimes the lack of trust dictated by the existence of a statutory release from professional secrecy.

\section{References}

Ambrożej E.A., Doradztwo podatkowe jako instrument ochrony praw podatnika w Polsce, Białystok 2016.

Jamroży M., Domaszyńska P., "XI Debata Podatkowa: Raportowanie schematów podatkowych”, Przegląd Podatkowy 7, 2019.

Ladziński A., Wasiul D., "O nieprawidłowej implementacji dyrektywy 2018/822 (MDR) i jej konsekwencjach”, Przeglad Podatkowy 5, 2019.

Piórkowska-Flieger J., "Commentary to Article 266", [in:] Kodeks karny. Komentarz, ed. T. Bojarski, Warszawa 2017, LEX/el.

Ustawa o doradztwie podatkowym. Komentarz, ed. A. Mariański, Warszawa 2010.

Wieśniak-Wiśniewska A., Czerwiński M., "Świat podatków po projekcie BEPS i jego wpływ na polskich podatników”, Przegląd Podatkowy 6, 2016.

Wilk M., "Ujawnianie schematów podatkowych a tajemnica zawodowa doradcy podatkowego", Przegląd Podatkowy 2, 2019.

\section{Legal references}

Council Directive (EU) 2018/822 of 25 May 2018.

The Act of 2 April 1997 Constitution of the Republic of Poland (Journal of Laws [Dz.U.] of 1997 no. 78 item 483 ).

The Act of 6 June 1997 Code of Criminal Procedure (Journal of Laws [Dz.U.] of 2020 item 30).

The Act of 6 June 1997 Criminal Code (Journal of Laws [Dz.U.] of 2019 item 1950).

The Act of 29 August 1997 - Tax Ordinance Act (consolidated text of the Journal of Laws [Dz.U.] of 2019 item 900).

The Act of 10 September 1999 Penal and Fiscal Code (Journal of Laws [Dz.U.] of 2020 item 19).

The Act of 23 October 2018 on amending the Personal Income Tax Act, the Corporate Income

Tax Act, the Tax Ordinance Act and certain other acts (Journal of Laws [Dz.U.] of 2018 item 2193).

Tax Advisory Act of 5 July 1996 (Journal of Laws [Dz.U.] 2020 item 130). 


\section{Judicial decisions}

Decision of the Court of Appeal in Kraków in the decision of 19 March 2009, case file no. II AKz 64/09, LEX no. 1222109.

Decision of the Court of Appeal in Warsaw of 15 May 2008, case file no. II AKz 294/08, LEX no. 509771.

Decision of the Court of Appeal in Wrocław of 18 September 2009, case file no. II AKz 472/09, LEX no. 1451899.

Judgement of the Constitutional Tribunal of 22 November 2004, case file no. SK 64/2003, LEX no. 133768. 